JPSCR: Journal of Pharmaceutical Science and Clinical Research, 2021, 03, 339-348

DOI: 10.20961/jpscr.v6i3.51887

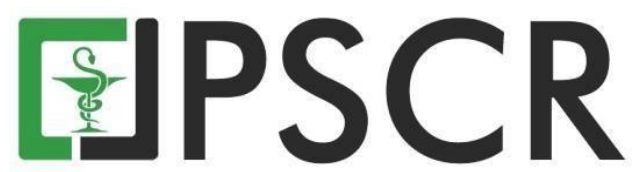

\title{
Penggunaan Low Molecular Weight Heparin untuk Pasien COVID-19 dengan Kehamilan: Studi Literatur
}

\author{
Rr Asih Juanita ${ }^{1}$, Herleeyana Meriyani ${ }^{1 *}$, Dwi Arymbhi Sanjaya ${ }^{1}$, Nyoman Budiartha \\ Siada $^{1}$ dan Putu Sukma Purnamasari ${ }^{2}$ \\ ${ }^{1}$ Departemen Farmakologi dan Farmasi Klinik, Fakultas Farmasi, Universitas Mahasaraswati Denpasar, Jl. \\ Kamboja No. 11A, Bali, Indonesia, 80233. \\ ${ }^{2}$ Program Studi Diploma III Farmasi, Universitas Mahasaraswati Denpasar, J1. Kamboja No. 11A, Bali, Indonesia, \\ 80233. \\ *email korespondensi: herleeyana.m@unmas.ac.id \\ Received 09 June 2021, Accepted 18 November 2021, Published 20 November 2021
}

\begin{abstract}
Abstrak: COVID-19 atau Coronavirus Disease 2019 merupakan penyakit yang disebabkan oleh virus SARS-CoV-2. COVID-19 dengan kehamilan sangat meningkatkan risiko Tromboemboli Vena (TEV), sehingga diperlukan terapi antikoagulan. Heparin jenis low molecular weight heparin atau LMWH dipilih untuk kehamilan dan menyusui. Tujuan dari penelitian ini yaitu memuat informasi mengenai pemberian profilaksis TEV berupa LMWH pada ibu hamil dengan COVID-19. Metode yang digunakan adalah studi kajian pustaka yang mengumpulkan dan menelaah informasi dari beberapa jurnal atau pedoman terkait dosis pemberian, efek samping, dan rekomendasi pemberian LMWH pada pasien COVID-19 dengan kehamilan oleh badan kesehatan dunia. Hasil kajian yang telah dilakukan, dosis LMWH sebagai profilaksis TEV adalah $4000 \mathrm{IU}(40 \mathrm{mg})$ melalui subkutan sekali sehari. Efek samping penggunaan LMWH memiliki efek yang tidak diinginkan, diantaranya trombositopenia, hipersensitivitas pada kulit, nekrosis pada kulit, pendarahan, osteoporosis dan fraktur. Dalam penggunaannya untuk ibu hamil dengan resiko TEV akibat COVID-19, LMWH memberikan manfaat yang lebih besar. LMWH berperan penting dalam terapi antikoagulan yang dibutuhkan dalam pengobatan modern. Penggunaan LMWH pada pasien COVID-19 dengan kehamilan, harus mempertimbangkan rasio manfaat dan efek samping agar tidak membahayakan kondisi ibu dan janin.
\end{abstract}

Kata kunci: Corona Virus Disease-19; dosis; efek samping; kehamilan; low molecular weight heparin

Abstract. Low Molecular Weight Heparin Therapy for COVID-19 Patients with Pregnancy: an overview. COVID-19 or Coronavirus Disease 2019 is a disease caused by the SARS-CoV-2 virus. COVID-19 Patients with Pregnancy greatly increases the risk of Venous Thromboembolism (TEV), thus anticoagulant therapy is required. Low molecular weight heparin or LMWH has been chosen for pregnancy and lactation. The purpose of this study was to contain information regarding the provision of TEV prophylaxis in the form of LMWH to pregnant women with COVID-19. This study was an overview that collects and explore information from several journals or guidelines related to dosage, side effects, and recommendations for LMWH use in COVID-19 patients with pregnancy by the world health organization. Based on the results, the prophylaxis dose of LMWH for TEV is $4000 \mathrm{IU}$ (40 mg) subcutaneously once daily. The use of LMWH has several adverse effects for instance: thrombocytopenia, skin hypersensitivity, skin necrosis, bleeding, osteoporosis and fractures. The use of LMWH during pregnancy in TEV due to COVID-19, LMWH provides greater benefits. LMWH plays an important role in anticoagulant therapy. The use of LMWH in 
COVID-19 patients with pregnancy, must consider the ratio of risk and benefits thus not to harm the mother and fetus.

Keywords: Corona Virus Disease-19; dosage; adverse reaction; pregnancy; low molecular weight heparin

\section{Pendahuluan}

COVID-19 atau Coronavirus Disease 2019 telah menjadi ancaman bagi kesehatan masyarakat global sejak Desember 2019. COVID-19 adalah penyakit yang disebabkan oleh virus SARS-CoV-2 (Luan et al., 2020). Virus ini merupakan keluarga dari Coronavirus, seperti SARS-CoV dan MERS-CoV yang telah lebih dahulu diketahui penanganannya. Infeksi oleh virus ini ditandai oleh tiga pola klinis, yakni yang pertama adalah tidak ada gejala yang diklasifikasikan sebagai Orang Tanpa Gejala atau OTG (Riadi, 2019), yang kedua adalah bergejala penyakit ringan hingga sedang, dan yang ketiga adalah pneumonia atau peradangan pada parenkim paru (Luan et al., 2020).

Ibu hamil, nifas dan bayi merupakan kelompok yang rentan terinfeksi COVID-19. Ibu hamil memiliki risiko yang lebih tinggi untuk terjangkit penyakit berat, morbiditas dan mortalitas jika dibandingkan dengan populasi pada umumnya (Purnama et al., 2020). Namun hingga saat ini, pengetahuan mengenai infeksi COVID-19 yang berkaitan dengan kehamilan dan janin masih terbatas. World Health Organization (WHO) sebagai lembaga kesehatan dunia belum memiliki rekomendasi spesifik dalam menangani ibu hamil dengan COVID-19.

Data yang dihimpun dari kasus pada Coronavirus jenis lain (SARS-CoV dan MERSCoV) dan beberapa kasus COVID-19 yang pernah terjadi sebelumnya, efek samping pada ibu hamil dan janin dapat terjadi, antara lain berupa persalinan prematur dan gawat janin (Aziz, 2020). Akan tetapi, informasi ini tidak diketahui memiliki hubungan dengan infeksi virus SARS-CoV-2 pada ibu atau penggunaan obat dengan efek samping yang dapat mempengaruhi ibu hamil maupun janin.

Kehamilan secara fisiologis merupakan prothrombotic state yaitu suatu kondisi dimana tubuh mengalami perubahan fisiologi pada proses pembekuan darah, yang meningkatkan risiko pembekuan darah pada pembuluh darah dan membentuk trombus di vena yang disebut tromboemboli vena (TEV) (Tambunan et al., 2019). Kehamilan dengan COVID-19 sangat meningkatkan risiko TEV, sehingga diperlukan terapi antikoagulan untuk mencegah terjadinya tromboemboli vena. Pemberian heparin, baik dalam bentuk unfractioned heparin (UFH), low molecular weight heparin (LMWH), dan aspirin dosis rendah bukan merupakan suatu kontraindikasi pada kehamilan dan menyusui (Faqih, 2020). LMWH lebih dipilih daripada UFH karena memiliki profil farmakokinetik yang lebih dapat diprediksi, insiden kejadian reaksi 
obat yang tidak dikehendaki lebih rendah, dan memiliki khasiat yang lebih besar (Mohzari et al., 2021).

Penelitian sebelumnya belum ada kajian mengenai efektivitas terapi penggunaan LMWH pada kondisi kehamilan. Maka dari itu, untuk mencapai efektivitas terapi dengan tetap mempertimbangkan kejadian efek samping penggunaan LMWH pada kondisi kehamilan, dilakukan suatu kajian yang bertujuan untuk memuat informasi mengenai pemberian profilaksis tromboemboli vena berupa low molecular weight heparin (LMWH) pada kehamilan dengan COVID-19. Pengkajian dilakukan berdasarkan dosis pemberiannya, efek sampingnya, dan rekomendasi pemberiannya oleh badan kesehatan dunia.

\section{Bahan dan Metode}

Artikel ini merupakan studi kajian pustaka yang mengumpulkan dan menelaah informasi dari beberapa jurnal atau pedoman terkait dengan pemberian dan efek samping LMWH pada pasien COVID-19 dengan kehamilan. Studi kajian pustaka ini akan memberikan gambaran (overview) tentang pemberian dan efek samping LMWH pada pasien COVID-19 dengan kehamilan.

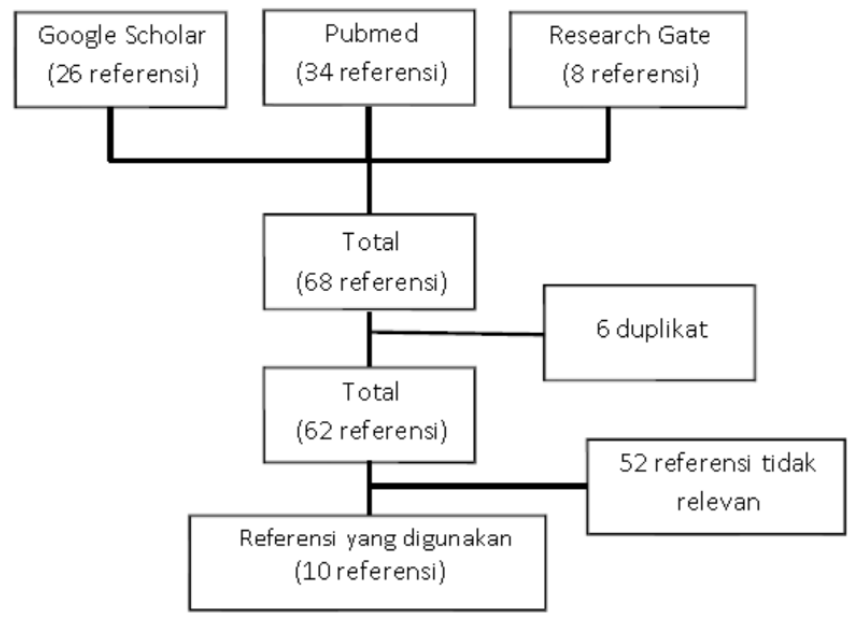

Gambar 1. Diagram pemilihan referensi artikel tentang pasien COVID-19 dengan kehamilan.

\subsection{Basis data yang digunakan}

Artikel disusun secara komprehensif dengan mengkaji hasil-hasil penelitian dan pedoman pengobatan yang telah dipublikasikan di berbagai jurnal internasional bereputasi, yang diakses dari basis data Google Scholar, PubMed, dan ResearchGate dengan memasukkan kata kunci [COVID-19 AND SARS-CoV-2 AND heparin AND “adverse reaction” AND pregnancy] pada basis data daring tersebut. Ditemukan 68 referensi terbaru dari tahun 2020 pada basis data terkait yang dikumpulkan melalui aplikasi Mendeley, dan 6 referensi dihilangkan karena terjadi duplikasi. 62 referensi tersebut ditelaah lebih lanjut dan hanya disaring yang terkait dengan treatment profilaksis tromboemboli vena pada ibu hamil dengan COVID-19, dosis dari 
treatment tersebut, mekanisme kerja obat, efek samping obat serta Pregnancy Categories yang mempengaruhi keamanan treatment pada wanita hamil. Sebanyak 52 referensi tidak relevan dengan kriteria, sehingga akhirnya hanya digunakan 10 referensi. Gambar diagram pemilihan referensi yang digunakan dalam studi literatur dapat dilihat pada Gambar 1.

\subsection{Basis data Uji Klinik}

Data uji klinik terapi tromboemboli vena pada pasien COVID-19 dengan kehamilan, dicari dengan menggunakan basis data ClinicalTrials.gov dengan kata kunci Venous Thromboembolism, COVID-19, dan pregnancy dengan menggunakan filter "recruiting".

\section{Hasil dan Pembahasan}

\subsection{COVID-19 menyebabkan tromboemboli vena (TEV)}

COVID-19 diduga berperan dalam menyebabkan terjadinya koagulasi darah. Fungsi koagulasi pada pasien dengan SARS-CoV-2 secara signifikan terganggu bila dibandingkan dengan orang sehat. Mekanisme pembekuan darah akibat serangan virus SARS-CoV-2 ini diawali dengan terjadinya sindrom pernafasan akut parah coronavirus 2 (SARS-CoV-2) menginfeksi sel yang memiliki fungsi untuk mengekspresikan reseptor permukaan angiotensinconverting enzyme (ACE-2) (Price et al., 2020). Menurut penelitian Xu et al (2020), protein spike (yang berbentuk seperti paku-paku yang menancap pada permukaan) virus SARS-CoV memiliki afinitas ikatan yang kuat dengan ACE2 manusia berdasarkan studi interaksi biokimia dan analisis struktur kristal. Ikatan dengan reseptor ACE2 inilah yang akan membantu virus SARS-CoV masuk ke dalam sel inangnya.

Tahap selanjutnya, terjadi replikasi aktif dan pelepasan virus dapat menyebabkan sel inang mengalami piroptosis (apoptosis pro-inflamasi) dan melepaskan DAMPs (damageassociated molecular patterns), mengaktifkan stres oksidan, dan menghasilkan pelepasan sitokin dan kemokin pro-inflamasi dan menyebabkan peradangan seperti yang diilustrasikan pada Gambar 2. Setelah itu, terjadi pelepasan sitoksin dari sel epitel, makrofag alveoli dan sel endotel (EC) selama peradangan, yang mengarah ke aktivasi jalur koagulasi ekstrinsik dan intrinsik untuk membuat trombin. Trombin berikatan dengan reseptor untuk mendorong pembentukan fibrin dari fibrinogen, aktivasi trombosit dan selanjutnya stabilisasi bekuan, juga menyebarkan peradangan lebih lanjut dan berakhir dengan aktivasi platelet-prothrombotic state.

Kehamilan adalah keadaan fisiologis yang menjadi predisposisi wanita terhadap komplikasi pernapasan akibat infeksi virus. Adanya perubahan fisiologis dalam sistem kekebalannya, wanita hamil lebih mungkin untuk mengalami prognosis yang lebih buruk saat terinfeksi virus (RCOG, 2020). Kehamilan menyebabkan terjadinya prothrombotic state, yaitu 
suatu kondisi dimana tubuh mengalami perubahan fisiologi pada proses pembekuan darah, yang meningkatkan risiko pembekuan darah pada pembuluh darah dan memicu trombus di vena yang disebut tromboemboli vena (TEV) (Tambunan et al., 2019). TEV menjadi salah satu penyebab tingginya angka mortalitas pada kehamilan dan menyebabkan kondisi patofisiologi yang kompleks untuk didiagnosa dan diobati. TEV dapat menyebabkan terjadinya emboli pada pulmonari paru dan deep-vein thrombosis (DVT). Emboli pada pulmonari paru adalah penyebab utama kematian ibu di negara maju (Airlangga, 2017).

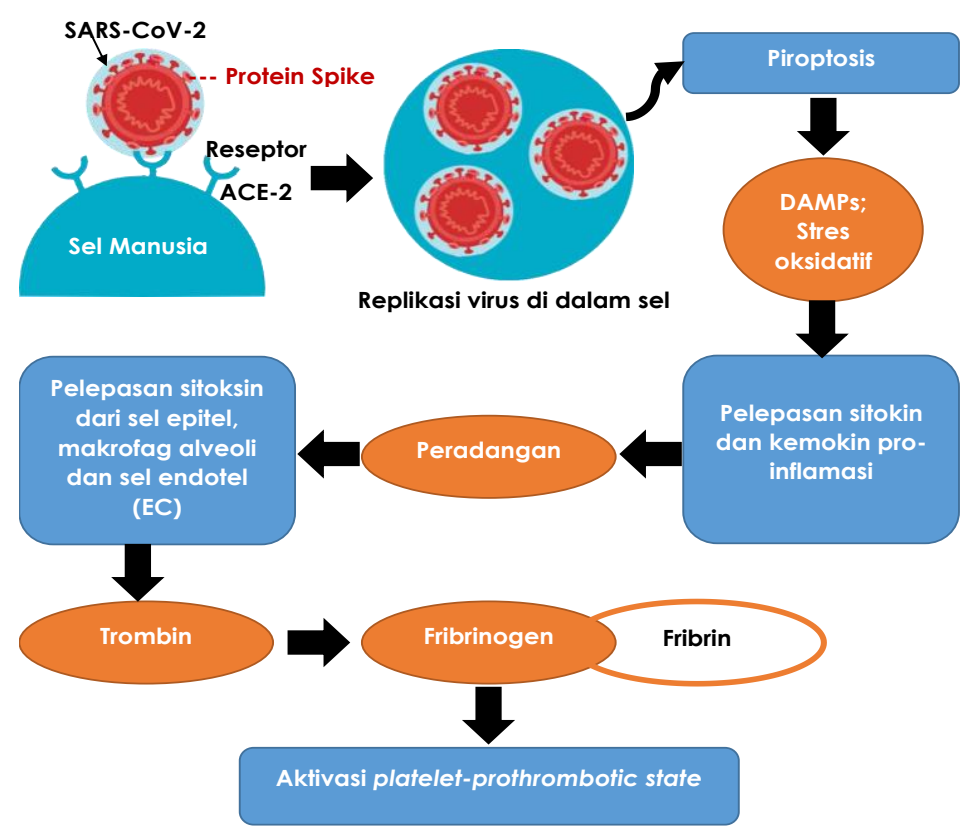

Gambar 2. Alur Mekanisme Dugaan Terjadinya Keadaan Trombosis pada Pasien COVID-19 (Diadaptasi dari Price et al., 2020).

Angka fatalitas kasus infeksi SARS-CoV pada wanita hamil mencapai 25\%. Namun, saat ini tidak ada bukti bahwa wanita hamil lebih rentan terhadap infeksi COVID-19 atau bahwa mereka yang terinfeksi COVID-19 lebih rentan mengalami komplikasi yang berat. Selain dampak infeksi COVID-19 pada wanita hamil, ada kekhawatiran yang berkaitan dengan efek potensial pada hasil akhir janin dan neonatal. Oleh karena itu, ibu hamil memerlukan perhatian khusus dalam kaitannya dengan pencegahan, diagnosis dan penatalaksanaan (Poon et al., 2020).

\subsection{Terapi profilaksis tromboemboli vena (TEV)}

Kajian yang telah dilakukan beberapa ahli didapatkan bahwa risiko kejadian tromboemboli terjadi pada pasien COVID-19 dan pada kondisi kehamilan kondisi ini menjadi lebih berisiko. Pada kehamilan terjadi peningkatan produksi trombin dan inflamasi intravaskuler maka sangat disarankan untuk segera memulai profilaksis pada semua ibu hamil yang menderita COVID-19, kecuali terdapat kontraindikasi yang jelas, seperti yang disarankan oleh Di Renzo dan Giardina, dalam American Journal of Obstetrics and Gynecology (2020). 
Disebutkan bahwa apabila obat yang dipilih memiliki kontraindikasi yang telah diketahui dan tinggi resikonya, maka sebaiknya tidak diberikan terapi profilaksis tersebut.

Heparin diberikan baik dalam bentuk unfractioned heparin (UFH), low molecular weight heparin (LMWH), dan aspirin dosis rendah diketahui tidak menimbulkan kontraindikasi pada kehamilan dan menyusui. Namun, pada kondisi kehamilan, LMWH menjadi pilihan pertama (Faqih, 2020). LMWH lebih dipilih daripada UFH karena memiliki profil farmakokinetik yang lebih dapat diprediksi, insiden yang lebih rendah dari reaksi obat yang tidak dikehendaki dan khasiat yang lebih besar (Mohzari et al., 2021). LMWH juga mudah dalam penggunaannya, tidak perlu melakukan pemantauan laboratorium secara umum. LMWH adalah antikoagulan yang paling umum digunakan untuk mencegah TEV pada pasien karena memiliki efek mencegah pembentukan trombin (Koyuncu, 2020). LMWH diketahui tidak melewati plasenta dan berisiko rendah terhadap paparan janin. LMWH memiliki manfaat potensial dibandingkan UFH, seperti ketersediaan hayati yang lebih tinggi, waktu paruh yang lebih lama, dan respons yang lebih dapat diprediksi. Faktor-faktor inilah yang membuat LMWH ideal untuk penggunaannya (Jacobson et al., 2020).

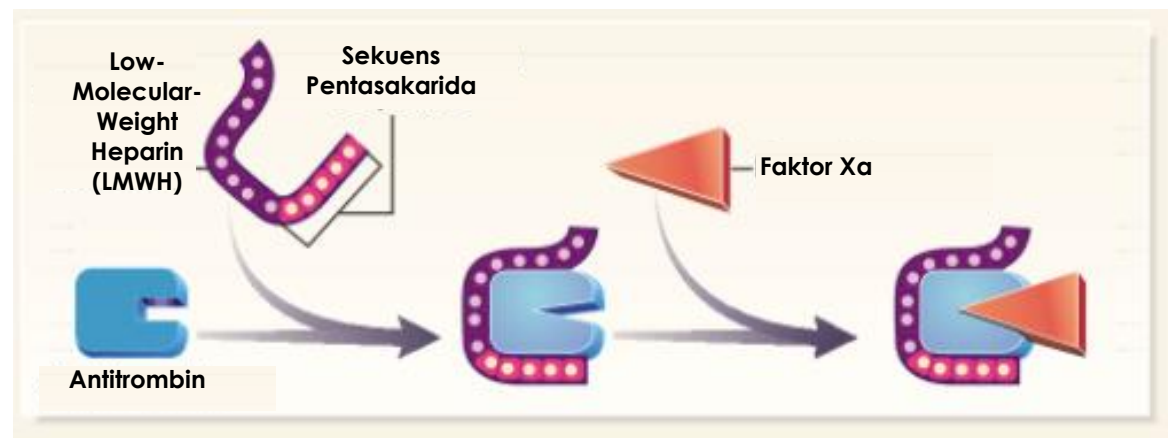

Gambar 3. Mekanisme kerja LMWH sebagai antikoagulan (Diadaptasi dari (Ofosu \& Barrowcliffe, 1990).

Mekanisme kerja LMWH yaitu dengan mengerahkan aktivitas antikoagulannya dengan mengaktifkan antitrombin (sebelumnya disebut antitrombin III), yang mempercepat inaktivasi enzim koagulasi trombin (faktor IIA), faktor Xa dan faktor IXA. Interaksi dengan antitrombin ini dimediasi oleh urutan pentasakarida yang unik seperti pada Gambar 3. Pengikatan pentasakarida ke antitrombin menyebabkan perubahan konformasi pada antitrombin yang menonjolkan aksinya dengan trombin dan faktor Xa sekitar seribu kali. Untuk menonaktifkan trombin, obat harus berikatan dengan trombin dan antitrombin, sehingga membentuk kompleks tersier. Mekanisme LMWH dalam menghambat koagulasi dengan mengaktifkan antitrombin III. Antitrombin III mengikat faktor Xa yang merupakan faktor koagulasi. Hal tersebut menghambat kerja dari faktor Xa. Mengikat faktor Xa menyebabkan protrombin tidak diaktifkan menjadi trombin, sehingga tidak mengubah fibrinogen menjadi fibrin, maka tidak terjadi pembekuan darah (Makris, 2018). 


\subsection{Rekomendasi dosis dan efek samping penggunaan Low Molecular Weight Heparin (LMWH) pada pasien COVID-19 dengan kehamilan}

LMWH dapat mengakibatkan terjadinya efek samping seperti perdarahan atau komplikasi lain yang harus dipantau selama pemberiannya. Oleh karena itu, informasi tentang dosis, efek samping dan rekomendasi pemberian LMWH pada pasien COVID-19 dengan kehamilan diperlukan agar memberikan gambaran dalam pengambilan keputusan terapi COVID-19 seperti yang telah dikaji dan disajikan pada Tabel 1.

Dosis penggunaan LMWH pada pasien COVID-19 dengan kehamilan beragam sesuai dengan kondisi pasien dan pertimbangan dokter. Namun, berdasarkan studi pustaka yang telah dilakukan (Tabel 1) empat dari sepuluh literatur merekomendasikan penggunaan LMWH pada COVID-19 dengan kehamilan dengan dosis $4000 \mathrm{IU}$ (40 mg) sekali sehari secara subkutan. Efek samping yang ditimbulkan dari pemberian LMWH pada kehamilan diantaranya dapat menimbulkan trombositopenia yang diinduksi heparin (HIT/heparininduced thrombocytopenia), hipersensitivitas pada kulit, nekrosis pada kulit, pendarahan, osteoporosis dan fraktur, seperti yang dirangkum pada Tabel 1.

HIT (heparininduced thrombocytopenia) adalah reaksi terkait antibodi yang serius yang mengakibatkan agregasi trombosit yang abnormal dan ireversibel, yang menyebabkan kejadian tromboemboli dan potensi kematian. Namun, berdasarkan meta-analisis, pasien yang diobati dengan heparin sering menunjukkan trombositopenia, tetapi HIT hanya terjadi pada sebagian kecil kasus ini dengan total kejadian HIT untuk UFH dan LMWH adalah 31/1255 pasien dan 1/1255 pasien (Onishi et al., 2016). Oleh karena itu, dapat disimpulkan bahwa kejadian HIT pada ibu hamil adalah kasus yang jarang terjadi.

Efek samping LMWH merupakan hipersensitivitas tipe lambat (delayed-type hypersensitivity, dikenal dengan DTH; yang disebut reaksi alergi tipe IV). Pasien biasanya datang dengan plak merah di tempat suntikan heparin. Hal ini apabila dibiarkan akan memicu terjadinya efek samping yang lain yaitu nekrosis kulit. Jika reaksi alergi kulit terjadi selama kehamilan, pilihan lain adalah beralih ke heparin lain dengan mempertimbangkan efek samping yang mungkin terjadi (Linnemann et al., 2016).

Heparin baik LMWH maupun UFH bekerja sebagai antikoagulan sehingga risiko pendarahan dapat terjadi. Pendarahan adalah salah satu reaksi merugikan yang terjadi pada lebih dari 2\% kasus penggunaan heparin (Onishi et al., 2016). Bukti risiko perdarahan pada kehamilan yang dikaji dari studi observasional, diketahui bahwa tingkat perdarahan pada kehamilan lebih tinggi dari 15,4\% dalam studi retrospektif di Eropa yang mencakup 254 wanita yang diobati dengan dosis terapi (Linnemann et al., 2016). 
J Pharm Sci Clin Res, 2021, 03

Tabel 1. Data informasi LMWH untuk kehamilan. Keterangan: PC : Pregnancy Category. FDA akan merubah aturan pelabelan produk dan obat untuk kehamilan. Kategori kehamilan A, B, C, D, dan X akan dihapuskan. Efek farmakologis dari obat telah menyebabkan atau mungkin dicurigai menyebabkan efek berbahaya pada janin atau neonatus namun tanpa menyebabkan malformasi. Efek ini mungkin dapat dipulihkan. Penggunaan harus dikonsultasikan lebih lanjut.

\begin{tabular}{|c|c|c|c|c|c|}
\hline Referensi & Karakteristik Pasien & Dosis yang Dianjurkan & Efek Samping & $\begin{array}{c}\text { FDA PC } \\
(\text { US })\end{array}$ & $\begin{array}{l}\text { TGA PC } \\
\text { (AU) }\end{array}$ \\
\hline (Favilli et al., 2020) & $\begin{array}{l}\text { Ibu hamil dengan Covid-19 yang } \\
\text { menggunakan obat-obatan covid-19, salah } \\
\text { satunya heparin }\end{array}$ & $\begin{array}{l}4000 \text { IU melalui subkutan sekali } \\
\text { sehari dan selama postpartum } \\
\text { apabila masih positif terhadap } \\
\text { virus. }\end{array}$ & $\begin{array}{l}\text { Osteoporosis dan } \\
\text { trombositopenia yang diinduksi } \\
\text { heparin. }\end{array}$ & \multirow{10}{*}{$\begin{array}{l}\text { Kategori } \\
\text { C pada } \\
\text { tahun } \\
2011^{*}\end{array}$} & \multirow{10}{*}{$\begin{array}{l}\text { Kategori } \\
\mathrm{C}^{* *}\end{array}$} \\
\hline (Zhai et al., 2020) & Pasien covid-19 (termasuk ibu hamil) & 4000 IU sekali sehari. & $\begin{array}{l}\text { Trombositopenia yang diinduksi } \\
\text { heparin (HIT / heparininduced } \\
\text { thrombocytopenia). }\end{array}$ & & \\
\hline (Mohzari et al., 2021) & $\begin{array}{l}\text { Ibu hamil yang mendapatkan enoxaparin } \\
\text { sebelum melahirkan }\end{array}$ & - & $\begin{array}{l}\text { Reaksi alergi, seperti } \\
\text { trombositopenia yang diinduksi } \\
\text { heparin dan reaksi } \\
\text { hipersensitivitas pada kulit. }\end{array}$ & & \\
\hline (Faqih, 2020) & $\begin{array}{l}\text { Pasien Covid-19 yang dirawat di rumah sakit } \\
\text { (termasuk ibu hamil, bersalin, dan menyusui) } \\
\text { yang diberikan antikoagulan profilaksis }\end{array}$ & 40 mg melalui subkutan. & Trombositopenia & & \\
\hline (Onishi et al., 2016) & $\begin{array}{l}\text { Pasien dengan Tromboemboli vena (TEV), } \\
\text { yang terdiri dari deep-vein thrombosis (DVT) } \\
\text { dan emboli paru (PE) yang diterapi dengan } \\
\text { LWMH kombinasi antagonis vitamin K }\end{array}$ & 170-200 IU/kg secara subkutan. & $\begin{array}{l}\text { Pendarahan, trombositopenia, } \\
\text { dan osteoporosis. }\end{array}$ & & \\
\hline (Karadağ et al., 2017) & $\begin{array}{l}\text { Pasien Recurrent pregnancy loss (RPL) dengan } \\
\text { trombofilia yang diberikan LMWH dan low } \\
\text { dose aspirin }\end{array}$ & $40 \mathrm{mg}$ per hari. & Trombositopenia, pendarahan. & & \\
\hline (Gargoum, 2018) & Ibu hamil dengan Tromboemboli vena (TEV) & 100-200 IU/kg secara subkutan. & $\begin{array}{l}\text { Nekrosis kulit, trombositopenia, } \\
\text { pendarahan. }\end{array}$ & & \\
\hline (Makris, 2018) & $\begin{array}{l}\text { Pasien dengan Tromboemboli vena (TEV) } \\
\text { (hamil dan tidak sedang hamil) }\end{array}$ & $\begin{array}{l}\text { Sekali sehari (Tidak disebutkan } \\
\text { jumlahnya). }\end{array}$ & $\begin{array}{l}\text { Pendarahan, alergi kulit, } \\
\text { osteoporosis, fraktur. }\end{array}$ & & \\
\hline $\begin{array}{l}\text { (Linnemann et al., } \\
\text { 2016) }\end{array}$ & $\begin{array}{l}\text { Pasien Tromboemboli vena (TEV) yang } \\
\text { menggunakan antikoagulan selama kehamilan } \\
\text { dan sesudah melahirkan }\end{array}$ & $\begin{array}{l}\text { 170-200 IU/kg secara subkutan } \\
\text { sekali sehari. }\end{array}$ & $\begin{array}{l}\text { Pendarahan, alergi kulit, } \\
\text { osteoporosis, trombositopenia. }\end{array}$ & & \\
\hline (Hecker et al., 2016) & Pasien emboli paru (PE) akut & - & $\begin{array}{l}\text { Pendarahan dan trombositopenia } \\
\text { yang diinduksi heparin. }\end{array}$ & & \\
\hline
\end{tabular}


LMWH juga memiliki efek samping pada tulang, yaitu osteoporosis. Osteoporosis merupakan penyakit tulang sistemik yang dicirikan oleh hilangnya massa mineral tulang, perubahan mikroarsitektur tulang, dan selanjutnya kerapuhan tulang yang mengakibatkan peningkatan risiko fraktur atau patah tulang. Selama kehamilan, kebutuhan kalsium meningkat, menyebabkan mobilisasi kalsium dan resorpsi tulang. Pada beberapa wanita, resorpsi berlebihan dari massa tulang mineral dapat terjadi (Jacobson et al., 2020). Fraktur dan osteoporosis yang terkait heparin telah diamati pada 2-5\% pasien yang diobati dengan heparin untuk jangka waktu yang lama dengan metode case reports yang dilakukan oleh Linnemann (2016). Meskipun ada laporan osteoporosis yang terjadi dengan penggunaan LMWH selama kehamilan dan postpartum, LWMH realtif aman dan efektif untuk digunakan pada kehamilan.

\section{Kesimpulan}

Heparin untuk masa mendatang berperan penting dalam terapi antikoagulan yang dibutuhkan dalam pengobatan modern. Penggunaan LMWH pada pasien COVID-19 dengan kehamilan, harus mempertimbangkan rasio manfaat dan efek samping agar tidak membahayakan kondisi ibu dan janin.

\section{Ucapan Terimakasih}

Terima kasih kepada Fakultas Farmasi Universitas Mahasaraswati Denpasar yang telah mendanai penulisan studi literatur ini melalui Program Hibah Internal Fakultas Farmasi tahun 2021 dengan nomor kontrak 041.8/E.4/FF-UNMAS/III/2021.

\section{Deklarasi Konflik Kepentingan}

Semua penulis menyatakan tidak ada konflik kepentingan terhadap naskah ini.

\section{Daftar Pustaka}

Airlangga, M.P. (2017). Tinjauan Kepustakaan : Diagnosis dan Tata Laksana Tromboemboli Pada Kehamilan. Qanun Medika, Vol 1 (2).

Aziz, M.A. (2020). Rekomendasi Penanganan Infeksi Virus Corona (Covid-19) Pada Maternal (Hamil, Bersalin Dan Nifas). Penanganan Infeksi Virus Corona Pada Maternal, 1 (3), pp.9-11.

Di Renzo, G.C. dan Giardina, I. (2020). Coronavirus disease 2019 in pregnancy: consider thromboembolic disorders and thromboprophylaxis. American Journal of Obstetrics and Gynecology, 223 (1), p.135. [Online]. Elsevier Inc. .

Faqih, M. (2020). Rekomendasi IDI: Pemberian Antikoagulan Profilaksis pada Pasien COVID-19 yang Dirawat di Rumah Sakit. Jakarta: Ikatan Dokter Indonesa (IDI).

Favilli, A., Mattei Gentili, M., Raspa, F., Giardina, I., Parazzini, F., Vitagliano, A., Borisova, A. V. dan Gerli, S. (2020). Effectiveness and safety of available treatments for COVID19 during pregnancy: a critical review. Journal of Maternal-Fetal and Neonatal Medicine, 0 (0), pp.1-14.

Gargoum, A.M. (2018). Treatment of Deep Vein Thrombosis and Pulmonary Embolism in Pregnancy. Libya: Libya International Medical University.

Hecker, M., Sommer, N., Hecker, A., Bandorski, D., Weigand, M.A., Krombach, G.A., Mayer, E. dan Walmrath, D. (2016). Pulmonary embolism. Medizinische Klinik - Intensivmedizin 
und Notfallmedizin, 111 (2), pp.163-178.

Jacobson, B., Rambiritch, V., Paek, D., Sayre, T., Naidoo, P., Shan, J. dan Leisegang, R. (2020). Safety and Efficacy of Enoxaparin in Pregnancy: A Systematic Review and MetaAnalysis. Advances in Therapy, 37 (1), pp.27-40. [Online]. Springer Healthcare.

Karadağ, C., Yoldemir, T., Karadağ, S.D., İnan, C., Dolgun, Z.N. dan Aslanova, L. (2017). Obstetric outcomes of recurrent pregnancy loss patients diagnosed with inherited thrombophilia. Irish Journal of Medical Science, 186 (3), pp.707-713.

Koyuncu, K. (2020). Thromboprophylaxis in Covid-19 positive pregnant women. Southern Clinics of Istanbul Eurasia, 31 (3), pp.281-286.

Linnemann, B., Scholz, U., Rott, H., Halimeh, S., Zotz, R., Gerhardt, A., Toth, B. dan Bauersachs, R. (2016). Treatment of pregnancy-associated venous thromboembolism Position paper from the Working Group in Women's Health of the Society of Thrombosis and Haemostasis (GTH). Vasa - European Journal of Vascular Medicine, 45 (2), pp.103118.

Luan, J., Lu, Y., Gao, S. dan Zhang, L. (2020). A potential inhibitory role for integrin in the receptor targeting of SARS-CoV-2. Journal of Infection, 81 (2), pp.318-356.

Makris, P.E. (2018). Low molecular weight heparin. Archives of Hellenic Medicine, 16 (4), pp.329-332.

Mohzari, Y.A., Asdaq, S.M.B., Bamogaddam, R.F., Alattas, K., Asalmi, S. dan Alshuraim, R.A. (2021). Postpartum prophylaxis of venous thromboembolism with anticoagulation: A case report. Journal of Taibah University Medical Sciences, 16 (2), pp.292-294. [Online]. Elsevier Ltd. Available from: https://doi.org/10.1016/j.jtumed.2020.12.016.

Ofosu, F.A. dan Barrowcliffe, T.W. (1990). Mechanisms of action of low molecular weight heparins and heparinoids. Bailliere's Clinical Haematology, 3 (3), pp.505-529.

Onishi, A., St Ange, K., Dordick, J.S. dan Linhardt, R.J. (2016). Heparin and anticoagulation. Frontiers in Bioscience - Landmark, 21 (7), pp.1372-1392.

Poon, L.C., Yang, H., Lee, J.C.S., Copel, J.A., Leung, T.Y., Zhang, Y., Chen, D. dan Prefumo, F. (2020). ISUOG Interim Guidance on 2019 novel coronavirus infection during pregnancy and puerperium: information for healthcare professionals. Ultrasound in Obstetrics and Gynecology, 55 (5), pp.700-708.

Price, L.C., McCabe, C., Garfield, B. dan Wort, S.J. (2020). Thrombosis and COVID-19 pneumonia: The clot thickens! European Respiratory Journal, 56 (1).

Purnama, Y., Dewiani, K. dan Yusanti, L. (2020). Pemutusan Rantai Penularan Covid-19 Pada Ibu Hamil, Nifas dan Menyusui di Kecamatan Ratu Agung Kota Bengkulu. Dharma Raflesia: Jurnal Ilmiah Pengembangan dan Penerapan IPTEKS, 18 (2), pp.190-198.

RCOG. (2020). Coronavirus ( COVID-19) Infection in Pregnancy. 11th ed. United Kingdom: Royal College of Obstetricians and Gynecologists.

Riadi, A. (2019). Pedoman dan Pencegahan Coronavirus (COVID- 19). Kementerian Kesehatan RI, 4, pp.1-214.

Tambunan, K.L., Pangalila, F.J.V., Wahjuprajitno, B., Hutajulu, S.V., Bur, R., Juzar, D.A., Tobing, D.P.L., Hermawan, H. dan Panji Santosa, Y. (2019). Konsensus Penatalaksanaan Tromboemboli Vena (Tev) Pada Penyakit Kritis. Jakarta : Perhimpunan Dokter Intensive Care Indonesia.

Zhai, Z., Li, C., Chen, Y., Gerotziafas, G., Zhang, Z., Wan, J., Liu, P., Elalamy, I. dan Wang, C. (2020). Prevention and Treatment of Venous Thromboembolism Associated with Coronavirus Disease 2019 Infection: A Consensus Statement before Guidelines. Thrombosis and Haemostasis, 120 (6), pp.937-948.

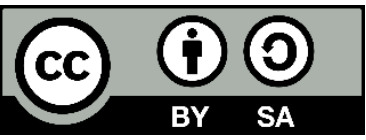

and conditions of the Creative Comm (https://creativecommons.org/licenses/by-sa/4.0/). 